\title{
LIMBAH KACA SEBAGAI PENGANTI SEBAGIAN AGREGAT HALUS UNTUK BETON RAMAH LINGKUNGAN
}

\author{
Muhammad Ramdhan Olii ${ }^{1)}$, Isran E.Poe ${ }^{2)}$, Ilyas Ichsan ${ }^{3)}$, Aleks Oliii ${ }^{4}$ \\ ${ }^{1,2,3,4)}$ Program Studi Teknik, Fakultas Teknik, Universitas Gorontalo \\ Email:kakaramdhanolii@gmail.com ${ }^{1)}$,poeisran@gmail.com ${ }^{2)}$ \\ ilyasichsan19@gmail.com ${ }^{3)}$,aleks.olii@yahoo.com ${ }^{4)}$ \\ DOI: http://dx.doi.org/10.29103/tj.v11i1.407
}

(Received: November 2020 / Revised: January 2021 / Accepted: January 2021)

\begin{abstract}
Abstrak
Limbah kaca menyebabkan masalah lingkungan yang kronis karena sangat sulit terurai di dalam tanah. Kaca banyak digunakan dalam kehidupan sehari-hari melalui produk manufaktur seperti kaca lembaran, botol, dan barang pecah belah. Kaca adalah bahan yang berpotensi besar untuk didaur ulang. Penggunaan kaca daur ulang membantu dalam penghematan energi dan perbaikan lingkungan. Meningkatnya kesadaran akan daur ulang kaca mempercepat perubahan penggunaan limbah kaca dengan bentuk berbeda di berbagai bidang. Salah satu kontribusinya yang signifikan adalah pada bidang konstruksi dimana limbah kaca digunakan kembali untuk produksi beton. Sifat-sifat beton yang mengandung limbah kaca sebagai agregat halus diteliti dalam penelitian ini. Limbah kaca digunakan sebagai pengganti sebagian agregat halus pada campuran beton $20 \%, 40 \%, 60 \%, 80 \%$ dan $100 \%$. Kuat tekan beton umur $3,7,14,21$ dan 28 hari dibandingkan dengan beton yang dibuat dengan agregat halus alami (beton normal). Hasil tersebut membuktikan bahwa kekuatan tertinggi diberikan oleh limbah debu kaca setelah 28 hari. Kuat tekan benda uji dengan variasi limbah kaca $20 \%$ dan $40 \%$ memiliki kuat tekan melebihi dari kuat tekan rencana $(24,95 \mathrm{Mpa})$, masing-masing 26,290Mpa dan 25,602 Mpa atau melebihi 5,4\% dan 2,6\%. Jika dibandingkan dengan kuat tekan rata-rata beton dan beton karakteristik beton normal, semua variasi limbah kaca mengalami penurunan. Di masa depan, penggunaan limbah kaca dalam beton ramah lingkungan akan memberikan dampak yang baik untuk konservasi sumber daya alam.
\end{abstract}

Kata kunci: Kaca, beton, kuat tekan, ramah lingkungan.

\begin{abstract}
Glass waste causes chronic environmental problems because it is very difficult to decompose in the soil. Glass is widely used in everyday life through manufactured products such as flat glass, bottles and glassware. Glass is a material with great potential for recycling. The use of recycled glass helps in saving energy and improving the environment. Increasing awareness of glass recycling is accelerating the change in the use of different forms of glass waste in various fields. One of its significant contributions is in the construction sector where glass waste is reused for concrete production. The properties of concrete containing glass waste as fine aggregate were investigated in this study. Glass waste is used as a partial replacement for fine aggregate in $20 \%, 40 \%, 60 \%, 80 \%$ and $100 \%$ concrete mixtures. The compressive strength of concrete aged 3, 7, 14, 21 and 28 days was compared with concrete made with natural fine aggregate (normal concrete). These results prove that
\end{abstract}


the highest strength is given by the waste glass dust after 28 days. The compressive strength of the test specimens with variations of glass waste of $20 \%$ and $40 \%$ had compressive strength exceeding the design compressive strength $(24.95 \mathrm{MPa})$, respectively $26.290 \mathrm{MPa}$ and $25.602 \mathrm{MPa}$ or exceeding $5.4 \%$ and $2.6 \%$. When compared with the average compressive strength of normal concrete and compressive strength of normal concrete characteristics, all variations of glass waste have decreased. In the future, the use of glass waste in environmentally friendly concrete will have a good impact on the conservation of natural resources.

Keywords: Glass, concrete, compressive strength, environmentally friendly.

\section{Latar Belakang}

Dalam beberapa dekade ini, pertumbuhan dunia konstruksi di semakin meningkat. Pertumbuhanan dunia kontruksi akan berbanding lurus dengan kebutuhan material kontruksi. Pada tahun 2018, sektor bangunan dan konstruksi bertanggung jawab atas 36\% konsumsi energi dan 39\% emisi karbon dioksida (CO2). Dari jumlah ini, 11\% disebabkan oleh produksi bahan bangunan dan produk seperti itu. seperti baja, semen dan kaca (IEA, 2019).

Beton merupakan pilihan utama yang paling banyak digunakan sebagai bahan dasar konstruksi bangunan karena dianggap memiliki keawetan dan kekuatan dalam pembangunan infrastruktur (Czarnecki and Kapron, 2010). Hal ini menyebabkan permintaan akan beton juga akan semakin meningkat yang akan mengganggu keseimbangan lingkungan dan merusak sumber daya alam. Oleh karena itu, dicari solusi yang efektif untuk mereduksi dampak negatif dari penggunaan beton yang berlebihan. Salah satu solusinya adalah beton ramah lingkungan (green concrete). Beton ramah lingkungan menggunakan lebih sedikit energi dalam produksinya dan menghasilkan lebih sedikit $\mathrm{CO}_{2}$ daripada beton normal sehingga dapat mendukung pembangunan berkelanjutan. Salah satu ciri beton ramah lingkungan adalah pemanfaatan bahan yang dapat didaur ulang atau pemanfaatan limbah sisa industri sebagai bahan pembuatan beton (Hendi et al., 2019). Salah satu bahan yang dimanfaatkan untuk beton ramah lingkungan adalah limbah kaca. Limbah kaca, kayu dan bahan lainnya yang dihasilkan Indonesia setiap harinya sebesar $12,7 \%$ dari total 65 juta ton sampah per hari. Kurang lebih 15 juta ton per hari mengotori ekosistem dan lingkungan karena tidak ditangani, 7\% sampah didaur ulang, dan 69\% sampah berakhir di Tempat Pembuangan Akhir (TPA). Ditambah lagi, limbah kaca sangat sulit diuraikan oleh mikroorganisme di dalam tanah. Oleh karena itu, pemanfaatan limbah kaca sebagai salah satu material pembuat beton menjadi penting dalam membantu mereduksi jumlah limbah kaca di Indonesia. Beberapa penelitian telah melakukan penelitian terkait pemanfaatan limbah kaca untuk penganti Sebagian material penyusun beton. Suhartini, et al. (2014); Srivastava et al. (2014); Liaqat, et al. (2018) memanfaatkan limbah kaca sebagai penganti sebagian agregat kasar. Namun, kaca bisa dikatakan paling sesuai sebagai penganti Sebagian agregat halus dan semen, karena komposisi kimia dan sifat fisiknya (Nassar and Soroushian, 2012). Limbah kaca yang digiling halus, menunjukkan sifat pozzolan yang meningkat seiring dengan berkurangnya ukuran partikel (Tamanna et al., 2016). Beberapa peneliti melaporkan bahwa semen dapat digunakan sebagai penganti sebagian semen ( Du and Tan 2014; Islam, et al. 2017; Tamanna et al. 
2016; Tamanna and Tuladhar 2020). Beberapa peneliti seperti Ali and AlTersawy (2012); Ganiron (2013); Aswad and Soeparyanto (2014); Ganiron (2014); Sadoon and Fan (2014); Rahim et al. (2015); Adaway and Wang (2015); Ogundairo et al. (2019); Seddik Meddah (2019) Małek et al. (2020) memanfaatkan pecahan limbah kaca sebagai penganti sebagian agregat halus dan melaporkan bahwa limbah kaca cukup baik digunakan dalam mengganti sebagian agregat halus dan menambah kuat tekan beton dengan variasi tertentu. Tujuan penelitian ini adalah menganalisis pengaruh pengantian sebagian agregat halus dengan limbah kaca (botol kaca) terhadap kuat tekan beton.

\section{Metode Penelitian}

Metode penelitian dilakukan beberapa tahapan. Tahapan tersebut adalah tahap persiapan limbah kaca sebagai pengganti sebagian agregat halus, agregat dan semen. Limbah kaca yang digunakan berasal dari botol kaca yang dihancurkan hingga menjadi pecahan kaya lolos di saringan No.4. Agregat kasar (batu pecah) yang digunakan pada penelitian ini berasal dari AMP (Asphalt Mixing Plant) Bongomeme dan agregat halus (pasir) berasal dari Sungai Bone. Semen yang digunakan merupakan Semen Portland (PC). Selanjutnya dilakukan tahap pengujian berupa pengujian karakteristik limbah kaca, agregat kasar dan halus yang dilakukan dengan cara:

- Pengujian kadar air agregat berdasarkan SNI 03-1971 sebagai berikut:

(1) Ambil material sebanyak yang diperlukan dengan cara perempatan;

(2) Timbang dan catat berat talam (A);

(3) Timbang dan catat material + talam (B);

(4) Hitung berat material $(\mathrm{C}=\mathrm{B}-\mathrm{A})$;

(5) Masukkan berat material ke dalam oven selama \pm 24 jam pada suhu $(110 \pm 5)^{\circ} \mathrm{C}$, lalu keluarkan dan biarkan sejenak hingga dingin;

(6) Kemudian material + talam ditimbang (D);

(7) Hitung berat material kering oven $(E=D-A)$.

$$
K_{a}=\frac{(C-E)}{E} \times 100
$$

Keterangan

$$
\begin{aligned}
& K_{a}=\text { kadar air }(\%) \\
& C=\text { berat material yang digunakan (gram) } \\
& E=\text { berat material kering setelah dioven (gram) }
\end{aligned}
$$

- Pengujian berat jenis kondisi SSD dan penyerapan air agregat kasar berdasarkan SNI 1969.

(1) Ambil material sebanyak sebanyak 11/2 kali kapasitas keranjang dengan cara perempatan;

(2) Material direndam selama \pm 24 jam;

(3) Material dikeluarkan dari bak perendam, dihamparkan di atas karung goni, kemudian dikeringkan permukaannya dengan menggunakan handuk dan dilap hingga mencapai kondisi SSD;

(4) Timbang dan catat keranjang kosong di udara (A); 
(5) Material kondisi SSD dimasukkan ke dalam keranjang sebanyak maksimum sesuai kapasitas keranjang;

(6) Timbang dan catat keranjang + material SSD di udara (B);

(7) Hitung material kondisi SSD di udara $(\mathrm{C}=\mathrm{B}-\mathrm{A})$;

(8) Timbang dan catat keranjang + benda uji SSD di dalam air dengan temperatur $(21.3 \pm 3)^{\circ} \mathrm{C}=(\mathrm{D})$;

(9) Timbang dan catat berat keranjang di dalam air (E);

(10) Hitung berat material dalam air $(\mathrm{F}=\mathrm{D}-\mathrm{E})$;

(11) Material dikeluarkan dari dalam keranjang kemudian dioven selama \pm 24 jam;

(12) Material yang sudah dioven dibiarkan hingga dingin lalu timbang dan catat material kering oven $(G)$.

$$
\begin{aligned}
& B S G_{S S D}=\frac{C}{C-F} \\
& A_{b}=\frac{C-G}{G}
\end{aligned}
$$

Keterangan

$$
\begin{array}{ll}
B S G_{S S D} & =\text { bulk specific grafity (ssd basic) } \\
A_{b} & =\text { absorsi }(\%) \\
C & =\text { berat agregat kondisi SSD di udara (gram) } \\
F & =\text { berat agregat dalam air (gram) } \\
G & =\text { berat contoh agregat kering oven (gram) }
\end{array}
$$

- Pengujian berat jenis dan penyerapan air agregat halus berdasarkan SNI 1970 sebagai berikut:

(1) Ambil material sebanyak yang diperlukan dengan cara perempatan;

(2) Material direndam sebanyak yang diperlukan selama \pm 24 jam;

(3) Material dikeluarkan dari bak perendam, dihamparkan di atas handuk dan digosok permukaannya hingga mencapai kondisi FFC (free flowing condition);

(4) Material dengan kondisi FFC dites dengan alat sand cone mold dengan 3 (tiga) lapisan. Lapisan 1 dan 2 dipadatkan 8 (delapan) kali tumbukan, sedangkan lapisan ke-3 (tiga) dengan 9 (sembilan) tumbukan. Proses pemadatan ini dilakukan sampai mencapai kondisi SSD, yaitu : apabila ketiga lapisan dipadatkan, cetakan kerucut material diangkat perlahanlahan secara vertikal dan material telah mengalami keruntuhan (failure);

(5) Timbang dan catat berat piknometer dalam kondisi kosong (A);

(6) Timbang dan catat material kondisi SSD sebanyak 500 gram (B);

(7) Material sebanyak 500 gram dimasukkan kedalam piknometer, kemudian ditambahkan dengan air sampai mencapai $\pm 90 \%$. Lalu bebaskan dari gelombung-gelembung udara dengan cara menggoyanggoyangkan piknometer;

(8) Rendamlah piknometer + material + air selama 15 menit;

(9) Timbang dan catat berat piknometer + material + air (C);

(10) Keluarkan material dari dalam piknometer lalu masukkan ke dalam oven selama \pm 24 jam pada suhu $(110 \pm 5)^{\circ} \mathrm{C}$; 
(11) Piknometer diisi dengan air sampai mencapai kapasitas yang sama sesuai dengan kapaistas piknometer + material + air dengan temperatur $(21.3 \pm 3)^{\circ} \mathrm{C}$ dengan ketelitian 0.1 gram, kemudian timbang dan catat beratnya (D)

(12) Keluarkan material dari dalam oven, biarkan hingga dingin, kemudian timbang dan catat beratnya $(\mathrm{E})$

$$
\begin{aligned}
& B S G_{S S D}=\frac{B}{D+B-C} \\
& A_{b}=\frac{B-E}{E} \times 100
\end{aligned}
$$

Keterangan

$$
\begin{array}{ll}
B S G_{S S D} & =\text { bulk specific grafity (ssd basic) } \\
A_{b} & =\text { absorsi }(\%) \\
A & =\text { berat piknometer (gram) } \\
B & =\text { berat benda uji kondisi SSD (gram) } \\
C & =\text { berat piknometer + material }+ \text { air } \\
D & =\text { berat piknometer + air (gram) } \\
E & =\text { berat material kering (gram) }
\end{array}
$$

- Pengujian analisis saringan agregat kasar, halus dan limbah kaca berdasarkan SNI 1968 sebagai berikut:

(1) Material sebanyak yang diperlukan dengan cara perempatan;

(2) Material ditimbang (A);

(3) Timbang dan catat berat dari masing-masing saringan dalam kondisi kosong (B);

(4) Material dimasukkan ke dalam susunan saringan dan disaring dengan menggunakan mesin penggetar selama \pm 15 menit;

(5) Timbang dan catat berat dari masing-masing saringan beserta isinya (C);

(6) Material yang tertahan pada masing- masing saringan dihitung $(\mathrm{D}=\mathrm{C}-$ B ).

$$
\begin{aligned}
& \% T=\frac{D}{A} \times 100 \\
& \% K_{l}=100-\% T \\
& F M=\frac{\sum \% K_{l}}{100}
\end{aligned}
$$

Keterangan

$$
\begin{aligned}
\% T= & \text { persentase tertahan }(\%) \\
D & =\text { berat material komulatif yang tertahan pada masing- } \\
& \text { masing saringan }(\mathrm{kg}) \\
A & =\text { total material yang digunakan }(\mathrm{kg}) \\
\% K_{l}= & \text { persentase kumulatif lolos }(\%) \\
F M & =\text { modulus kehalusan }
\end{aligned}
$$


- Pengujian berat isi agregat kasar, halus dan limbah kaca berdasarkan SNI 1973 sebagai berikut:

(1) Ambil material sebanyak yang diperlukan dengan cara perempatan;

(2) Timbang dan catat berat bohler dalam kondisi kosong (A);

(3) Masukkan material ke dalam bohler hingga penuh, ratakan permukaannya dengan menggunakan mistar perata;

(4) Bersihkan sisa-sisa material yang jatuh kedasar wadah bohler dengan menggunakan kuas;

(5) Timbang dan catat berat bohler beserta isinya (B);

(6) Hitung berat material $(\mathrm{C}=\mathrm{B}-\mathrm{A})$;

(7) Pengujian ini dilakukan dalam kondisi padat dan gembur dan dihitung berat rata-rata antara kondisi padat dan gembur.

$$
B_{v}=\frac{C}{V}=\frac{C}{\frac{1}{4} \pi d^{2} t}
$$

\section{Keterangan}

$$
\begin{aligned}
& B_{v}=\text { berat volume }(\mathrm{kg} / \mathrm{liter}) \\
& C=\text { berat contoh semen }(\mathrm{kg}) \\
& V=\text { volume bohler (liter) }
\end{aligned}
$$

Tata cara pemilihan campuran untuk beton normal, beton berat dan beton massa formula berdasarkan SNI 7656, Cara pengujian slump berdasarkan SNI 1972. Metode pembuatan dan perawatan benda uji beton di laboratorium berdasarkan SNI 2493. Pengujian kuat tekan beton dengan benda uji silinder berdasarkan SNI 1974. Persamaan yang digunakan untuk perhitungan kuat tekan beton adalah:

$$
f^{\prime} c=\frac{P}{A}
$$

Keterangan

$$
\begin{aligned}
f^{\prime} c & =\text { kuat desak beton }(\mathrm{Mpa}) \\
P & =\text { beban maksimum }(\mathrm{N}) \\
A & =\text { luas penampang benda uji }\left(\mathrm{mm}^{2}\right)
\end{aligned}
$$

\section{Hasil dan Pembahasan}

Agregat kasar dan halus untuk setiap wilayah memiliki karakteristik yang berbeda sehingga ketika menjadi bahan campuran beton akan membentuk karakteristik beton yang berbeda. Agregat kasar dan halus yang digunakan untuk campuran beton diuji terlebih dahulu berdasarkan SNI agar dapat diketahui mengetahui spesifikasi agregat untuk campuran beton. Tabel 1 menunjukkan bahwa agregat kasar dan halus yang digunakan memenuhi spesifikasi sebagai material campuran beton.

Perkiraan awal berat beton tanpa tambahan udara dengan agregat berukuran nominal maksimum sebesar $2345 \mathrm{~kg} / \mathrm{m}^{3}$. Perbandingan campuran terhadap kubikasi semen yang diperoleh adalah air 0,740: semen 1,000: agregat halus 1,910; dan agregat kasar 2,980. 
Tabel 1. Hasil Pengujian Limbah Kaca, Agregat Kasar dan Halus

\begin{tabular}{|c|c|c|c|c|c|c|c|}
\hline $\begin{array}{l}\text { No } \\
\cdot\end{array}$ & Jenis Pemeriksaan & $\begin{array}{c}\text { Hasil } \\
\text { Pengujian } \\
\text { Agregat } \\
\text { Kasar }\end{array}$ & Spek. & $\begin{array}{c}\text { Hasil } \\
\text { Pengujian } \\
\text { Agregat } \\
\text { Halus }\end{array}$ & Spek. & $\begin{array}{c}\text { Hasil } \\
\text { Pengujian } \\
\text { Limbah } \\
\text { Kaca }\end{array}$ & Sat. \\
\hline 1 & Modulus Kehalusan & 7,35 & $5-8$ & 2,51 & $\begin{array}{l}1,50- \\
3,80\end{array}$ & 3,69 & - \\
\hline 2 & Kadar Air & 0,59 & $0,5-3,0$ & 4,15 & $3-5$ & - & $\%$ \\
\hline 3 & Kadar Lumpur & 0,72 & Maks 1 & 1,65 & Maks 5 & - & $\%$ \\
\hline 4 & Apparent spesific grafity & 3,76 & - & 2,86 & - & - & - \\
\hline 5 & $\begin{array}{l}\text { Bulk specific grafity } \\
\text { (SSD basic) }\end{array}$ & 2,76 & - & 2,66 & - & - & - \\
\hline 6 & $\begin{array}{l}\text { Bulk specific grafity (on } \\
\text { dry basic) }\end{array}$ & 2,73 & - & 2,73 & - & - & - \\
\hline 7 & Absorbsi & 1,28 & - & 2,50 & - & - & $\%$ \\
\hline 8 & Abrasi & 19,46 & $\begin{array}{l}\text { Maks } \\
50\end{array}$ & - & - & - & $\%$ \\
\hline 9 & Berat Volume & 1581 & - & 1291 & - & 1663 & $\mathrm{~kg} / \mathrm{m}^{3}$ \\
\hline
\end{tabular}

Tabel 2 menunjukkan hasil mix design beton berdasarkan SNI 7656. Kuat tekan rencana beton pada penelitian sebesar 24,95 Mpa. Slump rencana yang digunakan adalah 75 - $100 \mathrm{~mm}$ dengan ukuran agregat dengan ukuran nominal agregat maksimum batu pecah adalah $19 \mathrm{~mm}$, oleh karena itu, banyaknya udara dalam beton $\%$ adalah $2 \%$.

Tabel 2. Mix Design Beton

\begin{tabular}{|c|c|c|c|}
\hline No. & Uraian & Satuan & Hasil \\
\hline 1 & Slump rencana & $\mathrm{mm}$ & $75-100$ \\
\hline 2 & Kuat tekan rata-rata yang ditargetkan & Mpa & 24,95 \\
\hline 3 & Perkiraan kebutuhan air pencampur & $\mathrm{kg}$ & 205 \\
\hline 4 & Kadar semen & $\mathrm{kg}$ & 336 \\
\hline 5 & Volume agregat kasar per satuan volume beton & $\mathrm{m}^{3}$ & 0,65 \\
\hline 6 & Agregat kasar & $\mathrm{kg}$ & 1028 \\
\hline 7 & Perkiraan awal berat beton segar & $\mathrm{kg}$ & 2345 \\
\hline 8 & Agregat halus & $\mathrm{kg}$ & 777 \\
\hline \multicolumn{4}{|c|}{ Perkiraan berat campuran untuk satu $\mathbf{m}^{3}$ kondisi kering } \\
\hline 9 & 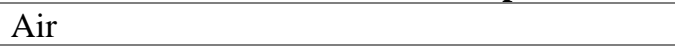 & $\mathrm{kg}$ & 199 \\
\hline 10 & Semen & $\mathrm{kg}$ & 336 \\
\hline 11 & Agregat kasar (kering) & $\mathrm{kg}$ & 1034 \\
\hline 12 & Agregat halus (kering) & $\mathrm{kg}$ & 809 \\
\hline \multicolumn{4}{|c|}{ Perbandingan campuran terhadap kubikasi semen } \\
\hline 13 & Air & & 0,740 \\
\hline 14 & Semen & & 1,000 \\
\hline 15 & Agregat halus & & 1,910 \\
\hline 16 & Agregat kasar & & 2,980 \\
\hline
\end{tabular}

Rasio air-semen yang diperoleh berdasarkan kuat tekan rencana adalah 0,611 dengan syarat beton tanpa tambahan udara. Volume agregat kasar kering oven per satuan volume beton untuk modulus kehalusan sebesar 2,66 dari agregat halus adalah 0,634 . 
Berdasarkan perbandingan campuran terhadap kubikasi semen pada Tabel 2, maka perbandingan tersebut dikonversi menjadi perbandingan campuran terhadap berat untuk 5 sampel beton kubus yang akan digunakan dan dapat dilihat pada Tabel 3. Benda uji yang digunakan berupa kubus berukuran $15 \times 15 \times 15 \mathrm{~cm}^{3}$. Variasi persentase limbah kaca yang digunakan adalah 20\%, 40\%, 60\% 80\%, dan $100 \%$ terhadap agregat halus. Setiap variasi limbah kaca menggunakan 5 sampel beton kubus dan 5 sampel beton kubus untuk beton normal (tanpa limbah kaca) sehingga total sampel yang digunakan adalah 30 sampel beton kubus. Limbah kaca yang perlu disiapkan untuk 25 sampel kubus beton seberat 45,05 kg yang telah lolos saringan no.4. Setiap satu sampel beton kubus diuji pada umur 3, 7, 14, 21, dan 28 hari.

Tabel 3. Perbandingan campuran terhadap berat untuk lima sampel kubus

\begin{tabular}{llcccccc}
\hline No. & Material & $\begin{array}{c}\text { Beton } \\
\text { Normal }\end{array}$ & $\begin{array}{c}\text { Beton } \\
\mathbf{2 0 \%} \\
\text { Pecahan } \\
\text { Kaca }\end{array}$ & $\begin{array}{c}\text { Beton } \\
\text { Pecahan } \\
\text { Kaca }\end{array}$ & $\begin{array}{c}\text { Beton } \\
\mathbf{6 0 \%} \\
\text { Pecahan } \\
\text { Kaca }\end{array}$ & $\begin{array}{c}\text { Beton } \\
\mathbf{8 0 \%} \\
\text { Pecahan } \\
\text { Kaca }\end{array}$ & $\begin{array}{c}\text { Beton } \\
\mathbf{1 0 0 \%} \\
\text { Pecahan } \\
\text { Kaca }\end{array}$ \\
\cline { 2 - 7 } & & $\mathbf{( k g )}$ & $\mathbf{( k g )}$ & $\mathbf{k g})$ & $\mathbf{( k g )}$ & $\mathbf{( k g )}$ & $\mathbf{( k g )}$ \\
\hline $\mathbf{1}$ & Air & 3,70 & 3,70 & 3,70 & 3,70 & 3,70 & 3,70 \\
\hline $\mathbf{2}$ & Semen & 6,23 & 6,23 & 6,23 & 6,23 & 6,23 & 6,23 \\
\hline $\mathbf{3}$ & Agregat Kasar & 19,19 & 19,19 & 19,19 & 19,19 & 19,19 & 19,19 \\
\hline $\mathbf{4}$ & Agregat Halus & 15,02 & 12,01 & 9,01 & 6,01 & 3,00 & - \\
\hline $\mathbf{5}$ & Limbah Kaca & - & 3,00 & 6,01 & 9,01 & 12,01 & 15,02 \\
\hline
\end{tabular}

Gambar 1 menunjukkan bahwa sampel beton kubus dengan variasi 20\% dan $40 \%$ limbah kaca memiliki kuat tekan melebihi dari kuat tekan rencana $(24,95$ Mpa), masing-masing 26,290 Mpa dan 25,602 Mpa atau melebihi 5,4\% dan 2,6\% dari kuat tekan rencana. Ini membuktikan bahwa variasi 20\% dan $40 \%$ limbah kaca masih dapat digunakan untuk mensubtitusi agregat halus, walaupun kecendrungan mengalami penurunan kuat tekan.

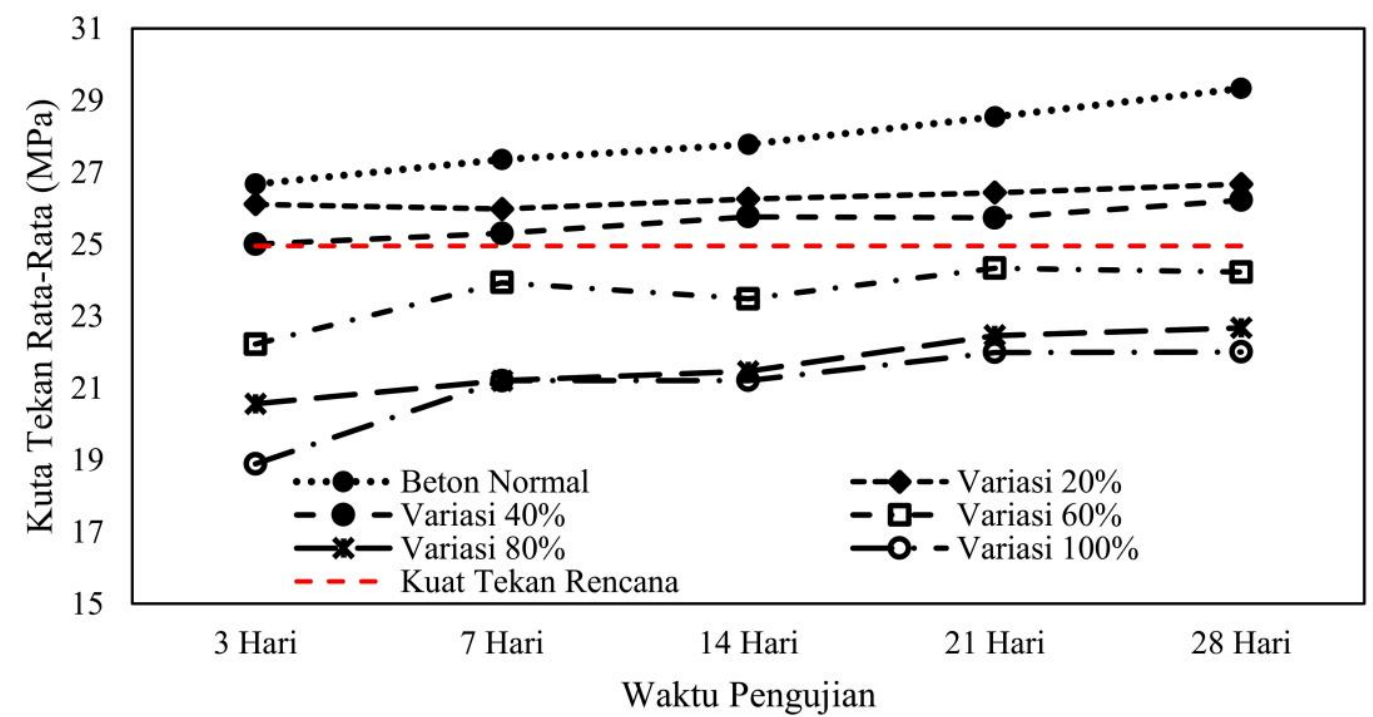

Gambar 1. Perbandingan Uji Kuat Tekan Rata-Rata Beton untuk Berbagai Variasi Limbah Kaca 
Hasil eksperimen Adaway and Wang (2015) menunjukkan kuat tekan beton 28 hari dengan variasi limbah kaca 30\% dapat meningkatkan 37,7\% di atas kuat tekan beton rencana $40 \mathrm{MPa}$. Namun, selisih hasil pengujian antara sampel yang mengandung variasi limbah kaca persentase $(15 \%, 20 \%, 25 \%, 30 \%, 35 \%$, dan $40 \%$ ) terlihat sangat kecil. Setelah pemeriksaan yang cermat, disimpulkan bahwa peningkatan kuat tekan lebih disebabkan oleh kualitas semen yang tinggi daripada kesalahan eksperimen atau peralatan. Penelitian-penelitian sebelumnya menemukan bahwa kecenderungan dari penurunan kuat tekan akibat dari pengurangan adhesi antara partikel limbah kaca dan pasta semen. Adaway and Wang (2015) menunjukkan bahwa sifat sudut dari partikel kaca dapat berkontribusi pada penurunan kekuatan beton. Jika limbah kaca digunakan dalam proporsi yang lebih tinggi, pasta semen yang tersedia di dalam campuran tidak mencukupi untuk memfasilitasi ikatan dengan semua partikel, yang mengakibatkan pembentukan rongga mikroskopis yang berdampak buruk pada kekuatan beton.

Variasi $20 \%$ dan $40 \%$ limbah kaca mengalami penurunan uji kuat tekan apabila dibandingkan dengan beton normal (27,934 Mpa), yaitu masing-masing $6,3 \%$ dan $9,1 \%$ dari kuat tekan beton normal (Gambar 1). Sampel beton kubus dengan variasi $60 \%, 80 \%$, dan $100 \%$ limbah kaca memiliki kuat tekan rata-rata lebih rendah dari kuat tekan rencana, masing-masing 23,636 Mpa; 21,670 Mpa; dan 21,058 Mpa.

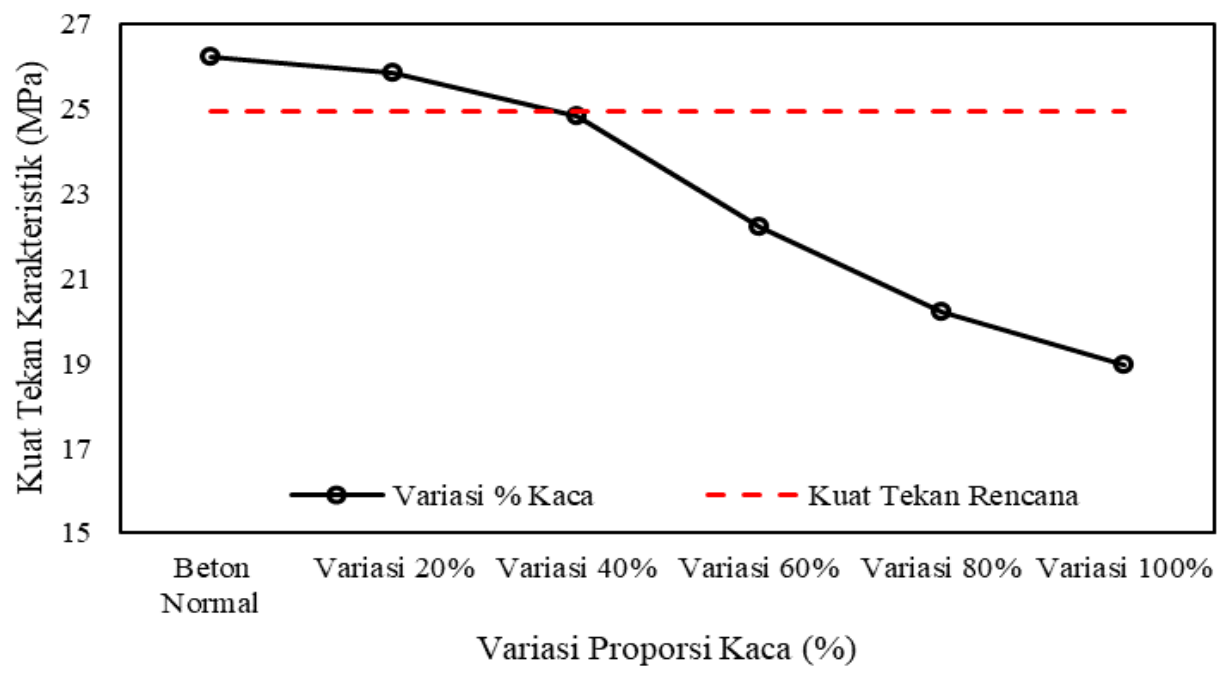

Gambar 2. Perbandingan Uji Kuat Tekan Beton Karakteristik untuk Berbagai Variasi Limbah Kaca

Beton dengan menggunakan limbah kaca juga memiliki kuat tekan beton karakteristik yang jauh berkurang apabila dibandingkan dengan kuat tekan beton karakteristik beton normal (Gambar 2). Hal ini menjelaskan bahwa limbah kaca hanya bisa digunakan dengan variasi maksimal $<40 \%$ limbah kaca, karena dapat melebihi kuat tekan beton rencana akan tetapi berkurang jika dibandingkan dengan kuat tekan rata-rata beton normal dan kuat tekan beton karakteritik beton 
normal. Rahim et al. (2015) berpendapat jumlah limbah kaca yang lebih tinggi menyebabkan penurunan daya serap air dan melemahnya kuat tekan beton. Limbah debu kaca tidak memiliki karakteristik kering permukaan jenuh (SSD) dan hal ini akan menyebabkan penurunan kuat tekan bila terdapat kelebihan air pada beton. Limbah kaca lebih lemah dan tidak menyerap lebih banyak air dibandingkan dengan agregat halus alami yang menyebabkan kuat tekan menjadi rendah.

Penelitian yang dilakukan oleh Ganiron (2013) memberikan hasil yang hampir sama dengan penelitian ini yaitu beton dengan variasi pengganti agregat halus dengan perbandingan limbah pecah terhadap agregat halus $25 \%, 50 \%, 75 \%$, $100 \%$ masing-masing adalah 10.96 MPa, 11.6 MPa, 12.08 MPa dan $10.12 \mathrm{MPa}$, atau semua variasi berada di bawah kuat tekan beton normal (tanpa limbah kaca) sebesar 25,54 MPa. Hal ini juga didukung oleh Ali and Al-Tersawy (2012) yang membuktikan kaca daur ulang digunakan untuk menggantikan agregat halus dengan proporsi $0 \%, 10 \%, 20 \%, 30 \%, 40 \%$, dan $50 \%$ mengalami penurunan seiring dengan peningkatan kadar limbah kaca. Hasil percobaan menunjukkan bahwa slump meningkat seiring dengan peningkatan kadar limbah kaca. Hasil penelitian menunjukkan bahwa limbah kaca berhasil digunakan untuk memproduksi beton self-compacting.

Hasil yang diperoleh dengan penelitian ini berbeda dengan penelitian yang diperoleh Sadoon and Fan (2014), yaitu penambahan limbah kaca hanya berpengaruh sedikit terhadap kuat tekan beton. Kuat tekan 28 hari tertinggi adalah $34,22 \mathrm{MPa}$ untuk campuran beton 20\% agregat halus limbah kaca, justru meningkatkan kuat tekan hingga 5,28\% dibandingkan dengan beton normal. Dapat juga diamati bahwa persentase peningkatan kuat tekan seiring bertambahnya usia secara keseluruhan meningkat dengan peningkatan limbah kaca sebagai agregat halus. Hal ini mungkin disebabkan oleh reaksi Pozzolan yang terdapat pada limbah kaca sehingga berkontribusi pada peningkatan kekuatan tekan pada 28 hari. Hal ini juga didukung oleh Rahim et al. (2015) yang memperoleh hasil pengujian nilai kuat tekan terbaik pada umur 28 hari sebesar $32,9 \mathrm{MPa}$ dari campuran beton berbahan agregat halus limbah kaca $10 \%$, yang merupakan peningkatan kuat tekan hingga 13,6\% dibandingkan dengan beton normal. Campuran beton kaca limbah $10 \%$ menunjukkan nilai kuat tekan yang lebih tinggi dibandingkan campuran beton normal, kecuali campuran beton $20 \%$ dan $50 \%$.

\section{Kesimpulan dan Saran \\ 4.1 Kesimpulan}

Hasil dari penelitian ini menegaskan bahwa pemanfaatan limbah kaca sebagai material pengganti sebagian agregat halus dalam beton cukup efektif dan dapat digunakan di masa mendatang. Pengaruh limbah kaca pada beton lebih terlihat pada umur 28 hari. Persentase optimum limbah kaca yang memberikan nilai kuat tekan maksimum adalah berada pada range 20-40\% walaupun dibandingkan dengan kuat tekan rata-rata beton dan beton karakteristik beton normal, semua variasi limbah kaca mengalami penurunan. Penelitian ini menunjukkan bahwa terdapat potensi yang menjanjikan untuk pemanfaatan limbah kaca dalam beton ramah lingkungan. 


\subsection{Saran}

Penyelidikan lebih lanjut dapat dipertimbangkan terkait efek jangka panjangnya pada sifat beton dan analisis pengaruh lain terhadap karakteristik beton, seperti kuat tarik, kuat belah, kuat lentur, kekakuan, keseragaman mutu beton, penyerapan, dan reaksi pozzolan yang terkandung pada limbah kaca terhadap beton.

\section{Ucapan Terima Kasih}

Kami mengucapkan terimakasih sebesar-besarnya kepada Fakultas Teknik Universitas Gorontalo dan Laboratorium Terpadu Universitas Gorontalo yang telah menfasilitasi penelitian ini.

\section{Daftar Kepustakaan}

Adaway, M. and Wang, Y. (2015) 'Recycled glass as a partial replacement for fine aggregate in structural concrete -Effects on compressive strength', Electronic Journal of Structural Engineering, 14(1), pp. 116-122.

Ali, E. E. and Al-Tersawy, S. H. (2012) 'Recycled glass as a partial replacement for fine aggregate in self compacting concrete', Construction and Building Materials, 35, pp. 785-791. doi: 10.1016/j.conbuildmat.2012.04.117.

Aswad, N. H. and Soeparyanto, T. S. (2014) 'Penggunaan Pecahan Botol Kaca Sebagai Agregat Kasar Pada Campuran Beton', Jurnal Stabilita, 2(1), pp. 101-108.

Czarnecki, L. and Kapron, M. (2010) 'Sustainable construction as a research area', International Journal of the Society of Material Engineering for Resources, 17(2), pp. 99-106. doi: 10.5188/ijsmer.17.99.

$\mathrm{Du}, \mathrm{H}$. and Tan, K. H. (2014) 'Waste glass powder as cement replacement in concrete', Journal of Advanced Concrete Technology, 12(11), pp. 468-477. doi: $10.3151 /$ jact.12.468.

Ganiron Jr, T. U. (2014) 'The Effect of Waste Glass Bottles as an Alternative Coarse Aggregate in Concrete Mixture', International Journal of ICT-aided Architecture and Civil Engineering, 1(2), pp. 1-10. doi: 10.21742/ijiace.2014.1.2.01.

Ganiron, T. J. (2013) 'Use of Recycled Glass Bottles as Fine Aggregates in Concrete Mixture', International Journal of Advanced Science and Technology, 61, pp. 17-28. doi: 10.14257/ijast.2013.61.03.

Hendi, A. et al. (2019) 'Mix design of the green self-consolidating concrete: Incorporating the waste glass powder', Construction and Building Materials, 199, pp. 369-384. doi: 10.1016/j.conbuildmat.2018.12.020.

IEA (2019) Global Status Report for Buildings and Construction 2019, IEA. Available at: https://www.iea.org/reports/global-status-report-for-buildingsand-construction-2019 (Accessed: 16 November 2020).

Islam, G. M. S., Rahman, M. H. and Kazi, N. (2017) 'Waste glass powder as

Limbah Kaca Sebagai Penganti Sebagian Agregat Halus Untuk Beton Ramah

Lingkungan - Muhammad Ramdhan Olii, Isran E.Poe, Ilyas Ichsan, Aleks Olii 
partial replacement of cement for sustainable concrete practice', International Journal of Sustainable Built Environment, 6(1), pp. 37-44. doi: 10.1016/j.ijsbe.2016.10.005.

Liaqat, M., Shah, M. L. and Baig, M. A. (2018) 'Effect of Waste Glass as Partial Replacement for Coarse Aggregate in Concrete', International Journal of Technical Innovation in Modern Engineering \& Science, 4(6), pp. 24552585.

Małek, M. et al. (2020) 'Effect of waste glass addition as a replacement for fine aggregate on properties of mortar', Materials, 13(14), pp. 1-19. doi: 10.3390/ma13143189.

Mohammed Seddik, M. (2019) 'Use of waste window glass as substitute of natural sand in concrete production', IOP Conference Series: Materials Science and Engineering, 603(3). doi: 10.1088/1757-899X/603/3/032011.

Nassar, R. U. D. and Soroushian, P. (2012) 'Strength and durability of recycled aggregate concrete containing milled glass as partial replacement for cement', Construction and Building Materials, 29, pp. 368-377. doi: 10.1016/j.conbuildmat.2011.10.061.

Ogundairo, T. O. et al. (2019) 'Sustainable use of recycled waste glass as an alternative material for building construction - A review', IOP Conference Series: Materials Science and Engineering, 640(1). doi: 10.1088/1757899X/640/1/012073.

Rahim, N. L. et al. (2015) 'Utilization of recycled glass waste as partial replacement of fine aggregate in concrete production', Materials Science Forum, 803, pp. 16-20. doi: 10.4028/www.scientific.net/MSF.803.16.

Sadoon, A. and Fan, M. (2014) 'Characteristics of concrete with waste glass as fine aggregate replacement', International Journal of Engineering and Technical Research (IJETR), 2(6), pp. 11-17.

Srivastava, V. et al. (2014) 'Glass Wastes as Coarse Aggregate in Concrete', Journal of Environmental Nanotechnology, 3(1), pp. 67-71. doi: 10.13074/jent.2013.12.132059.

Suhartini, A., Gunrati, A. S. S. and Azharie, H. (2014) 'Pengaruh Penambahan Tumbukan Limbah Botol Kaca Sebagai Bahan Subtitusi Agregat Halus Terhadap Kuat Tekan dan Kuat Lentur Beton', Jurnal bentang, 2(1), pp. 6680.

Tamanna, N. et al. (2016) 'Pozzolanic Properties of Glass Powder in Cement Paste', Journal of Civil Engineering, Science and Technology, 7(2), pp. 7581. doi: 10.33736/jcest.307.2016.

Tamanna, N. and Tuladhar, R. (2020) 'Sustainable Use of Recycled Glass Powder as Cement Replacement in Concrete', The Open Waste Management Journal, 13(1), pp. 1-13. doi: 10.2174/1874347102013010001. 